\title{
Obtaining and Characterization of Mesophilic Bacterial Consortia from Tropical Sludges Applied on Biohydrogen Production
}

\author{
Renan Pachiega ${ }^{1,2}$ (1) Isabel Kimiko Sakamoto ${ }^{3} \cdot$ Maria Bernadete Varesche $^{3} \cdot$ Rafael Rodrigues Hatanaka $^{1} \cdot$ \\ José Eduardo de Oliveira ${ }^{1}$. Sandra Imaculada Maintinguer ${ }^{2,4}$
}

Received: 19 January 2017 / Accepted: 27 December 2017 / Published online: 30 January 2018

○) Springer Science+Business Media B.V., part of Springer Nature 2018

\begin{abstract}
The biohydrogen production from different tropical sludges of biologic treatment plants was investigated in anaerobic batch reactors fed with sucrose in concentrations similar to food wastewaters. The tropical sludges tested were: I-granular sludge from a upflow anaerobic sludge blanket (UASB) reactor treating brewery wastewater; II-facultative anaerobic sludge from sedimentation pond treating domestic sewage; III—granular sludge from UASB reactor treating domestic sewage. The anaerobic batch reactors fed with $2 \mathrm{~g} \mathrm{~L}^{-1}$ of sucrose at $\mathrm{pH} 5.5$ and $37^{\circ} \mathrm{C}$ showed higher production of $\mathrm{H}_{2}$ than all tropical sludges tested. The maximum yield was $2.0 \mathrm{~mol} \mathrm{H}_{2}$ mol of sucrose ${ }^{-1}$. The intermediary products during fermentation were acetic and butyric acids. Therefore, the bioproduction probably followed both the acetic acid and butyric acid route. A wide diversity of hydrogen producing bacteria identified as Clostridium sp., Bacillus megaterium, Staphylococcus sp., Bacillus subtilis and Lactobacillus sp. was observed by phylogenetic analysis. Tropical sludges from biologic treatment plants can be applied on biohydrogen production.
\end{abstract}

Keywords Anaerobic bacteria $\cdot$ Clostridium $\cdot$ Denaturing gradient gel electrophoresis $\cdot$ Lactobacillus $\cdot$ Sucrose $\cdot 16 \mathrm{~S}$ RNA · TOGA gas analyzer

\section{Introduction}

One of the most critical issues in biologic treatment plants of wastewaters is the sludge excess generated and it takes up about $60 \%$ of the operational costs with it management and disposal [1]. Besides the excessive cost, the disposal of sewage sludge is realized in landfills and it exacerbates the problem of management of municipal solid waste due to its

Renan Pachiega

renanpachiega@gmail.com

1 CEMPEQC - Center for Monitoring and Research of the Quality of Fuels, Biofuels, Crude Oil, and Derivatives, Institute of Chemistry, Unesp, Araraquara, SP 14801-970, Brazil

2 IPBEN - Bioenergy Research Institute, Unesp, Rio Claro, SP 13500-230, Brazil

3 Department of Hydraulics and Sanitation, School of Engineering of São Carlos, University of São Paulo, São Carlos, SP 13563-120, Brazil

4 UNIARA - University of Araraquara, Araraquara, SP 14801-320, Brazil high organic load and its hazardous potential. An ideal way to solve sludge-associated problems is to use it as feedstock for bioenergy and biofuels production, such as biogas generation in fermentation processes of treatment with wastewaters as carbon source.

Hydrogen gas $\left(\mathrm{H}_{2}\right)$ is an effective non-pollutant, cheap and renewable source of energy. Aiming this energetic potential, the hydrogen gas production increased worldwide ( 6-10\%). However, it is not available in nature, so methods to produce it are being studied all over the world. The use of bacteria consortia can be found in photo-fermentation, bio-photolysis and dark fermentation. Among these, the dark fermentation route does not require light or oxygen and has a high hydrogen production rate [2].

Various sources of inocula have been tested, and they had confirmed efficiency on hydrogen production, such as soil samples, sludge from domestic sewage treatment and wastewater treatment from industrial plants, among others [3]. However, these possibilities are mostly described for temperate climates. There are only a few studies about hydrogen production with tropical inocula, such as Brazil, where the annual average temperatures are around $28^{\circ} \mathrm{C}$, which is ideal 
for bacterial growth [3]. Also, there are few studies on the diversity of hydrogen producing bacteria coming from tropical sludges of biological treatment plants.

Sugars such as sucrose are present in many wastewaters from Brazilian agroindustries. Brazil is the main citrus and ethanol from sugar cane producer in the world. Annually the sugarcane production is approximately 716 million tons, which corresponds to $43 \%$ of worldwide production [4]. The area planted with sugarcane have increased from $\sim 1.4$ to 7 million ha, from 1960 to 2007 [5]. This kind of crop have been increasing even much more due to the low pollution power of ethanol. The Central region of São Paulo State-Brazil, which this study was carried out, is one of the most powerful ethanol producers and therefore the one of the biggest areas with sugarcane plantation [6]. The biggest company of ethanol fuel in Brazil is in the region of Ribeirão Preto and this region embrace 6 of the biggest sugarcane mills companies [7]. With these production of sugarcane and ethanol fuel we have a potential amount of sucrose being discarded with the mill's wastewater. The sucrose is removed as residual sugar in the sugarcane bagasse [4] which contributes with high potential of these kind of wastewater to be applied on hydrogen production in the future. Citrus industries from Brazil generate 8.4 million tons in 2014 [8]. Stillage- the main effluent generated from sugar cane processing industries for producing ethanol-and in other effluents from food industry of candies and soft drinks, for example [3], generate sucrose at concentrations that vary from 0.7 to $2.0 \mathrm{~g} \mathrm{~L}^{-1}$ [9]. However, there are few studies on hydrogen production from wastewaters with low concentrations of sucrose [10]. The hydrogen arising from these sources can be reused for energy generation. These facts encourage studies on the application of anaerobic sludges, which are used for the treatment of sewage and industrial wastewaters in biologic processes, for hydrogen generation with sucrose in concentrations about to $2.0 \mathrm{~g} \mathrm{~L}^{-1}$. Many saccharides like glucose, hexoses, and polymers like starch and cellulose show different rates in hydrogen production per mole of organic substrate, depending on the fermentation route leading to carboxylic acids and/or alcohols. The acids produced are mainly lactic, acetic and butyric. The percentages of $\mathrm{H}_{2}$ produced in these processes may vary between 60 and $90 \%$ $(\mathrm{v} / \mathrm{v})$ of the total amount of gas produced [11]. Other gases can be generated, like carbon dioxide $\left(\mathrm{CO}_{2}\right)$, methane $\left(\mathrm{CH}_{4}\right)$, hydrogen sulfide $\left(\mathrm{H}_{2} \mathrm{~S}\right)$ and oxygen $\left(\mathrm{O}_{2}\right)$ [12].

The increase of hydrogen production is related to a mixture of byproducts, such as acetic acid and butyric acid; and the decrease of hydrogen production is associated to the formation of propionic acid and by products that are lesser reduced, such as alcohols and lactic acid [9].

The fermentative production of hydrogen can be facilitated by the inactivation of methanogenic microorganisms [9] since they may be present in the inocula and consume hydrogen gas during the anaerobic processes. Avoiding the methanogenic microorganisms, some actions have been studied, such as pH control, dry heat treatment, heat shock, freezing and thawing or dry heat and desiccation. Among the pretreatments that shows higher efficiency in inactivation and hydrogen production, there is the heat shock [15]. It can be an effective way to avoid hydrogen consuming microorganisms [13] and favor the development of hydrogen producing bacteria. To that end, the tropical sludges from three different biologic treatment plants were applied for the biohydrogen production with sucrose as substrate in concentrations frequently found in mill's wastewaters and domestic sewages. Most probable number (MPN) analyses were performed to estimate the total of anaerobic bacteria and hydrogen producing bacteria.

\section{Materials and Methods}

\section{Sources of Inoculum}

The inocula were from tropical sludges: I-granular sludge from a upflow anaerobic sludge blanket (UASB) reactor treating brewery wastewater (Araraquara-SP-Brazil); IIfacultative anaerobic sludge from sedimentation pond treating domestic sewage (Araraquara-SP-Brazil); III-granular sludge from UASB reactor treating domestic sewage (São José do Rio Preto-SP-Brazil). The granules of sources I, II and III were broken, separately, in a mortar and pestle.

\section{Microbial Consortium Obtained and Growth Conditions}

The cellular suspensions (20\% v/v) from inocula I, II and III were reactivated separately in anaerobic batch reactors $(100 \mathrm{ml})$ using sterile $\left(120^{\circ} \mathrm{C}, 20 \mathrm{~min}\right)$ PYG medium [glucose $\left(10.0 \mathrm{~g} \mathrm{~L}^{-1}\right)$, peptone $\left(5.0 \mathrm{~g} \mathrm{~L}^{-1}\right)$, yeast extract $\left(5.0 \mathrm{~g} \mathrm{~L}^{-1}\right)$, and meat extract $\left.\left(5.0 \mathrm{~g} \mathrm{~L}^{-1}\right)\right]$, under $\mathrm{N}_{2} 100 \%$ atmosphere at $37{ }^{\circ} \mathrm{C}$ during $96 \mathrm{~h}$. Afterwards, these samples were submitted to heat treatment at $90{ }^{\circ} \mathrm{C}$ for $15 \mathrm{~min}$, in order to inactivate hydrogen consumers and to obtain spore-forming anaerobic bacteria $[15,16]$. After that, serial dilutions on PYG media at $\mathrm{pH} 5.5$ were performed and the resulting cultures were used for the inoculation of the anaerobic batch reactors.

\section{Operation of the Anaerobic Batch Reactors}

The adapted cultures were centrifuged $\left(9000 \mathrm{rpm}\right.$ at $4{ }^{\circ} \mathrm{C}$ for $6 \mathrm{~min}$ ) and the cell pellets were suspended in new culture media, with the following composition $\left(\mathrm{g} \mathrm{L}^{-1}\right)$ [14]: Solution A $\left[\mathrm{NiSO}_{4} \cdot 6 \mathrm{H}_{2} \mathrm{O}(0.50), \mathrm{FeSO}_{4} \cdot 7 \mathrm{H}_{2} \mathrm{O}(2.50), \mathrm{FeCl}_{3} \cdot 6 \mathrm{H}_{2} \mathrm{O}\right.$ (0.25), $\left.\mathrm{CoCl}_{2} \cdot 2 \mathrm{H}_{2} \mathrm{O}(0.04)\right]$; Solution $\mathrm{B}\left[\mathrm{CaCl}_{2} \cdot 6 \mathrm{H}_{2} \mathrm{O}\right.$ 
(2.06)]; Solution $\mathrm{C}$ [ $\left.\mathrm{SeO}_{2}(0.14)\right]$; Solution $\mathrm{D}\left[\mathrm{KH}_{2} \mathrm{PO}_{4}\right.$ (5.36), $\mathrm{K}_{2} \mathrm{HPO}_{4}(1.30), \mathrm{Na}_{2} \mathrm{HPO}_{4} \cdot \mathrm{H}_{2} \mathrm{O}(2.76)$ two vitamin solutions $\left(\mathrm{mg} \mathrm{L}^{-1}\right)$; solution $\mathrm{E}$ [biotin (10.0); p-aminobenzoic acid (40.0)]; and solution $\mathrm{F}$ [B $\mathrm{B}_{12}$ vitamin (40.0)] [13]. The culture media contained peptone $\left(1.0 \mathrm{~g} \mathrm{~L}^{-1}\right)$, urea $\left(0.04 \mathrm{~g} \mathrm{~L}^{-1}\right)$ and solutions $\left(\mathrm{mL}^{-1}\right)$ : A 2.0, B 2.0, C 2.0, D 2.0, vitamin solutions (E) 2.0, (F) 2.0 [14]. The $\mathrm{pH}$ was adjusted to 5.5. The culture media were filtered through a previously sterilized $0.22 \mu \mathrm{m}$ Millipore membrane.

Anaerobic batch reactors ( $2 \mathrm{~L}$ ) capped with butyl rubber stoppers were fed with sucrose $\left(2 \mathrm{~g} \mathrm{~L}^{-1}\right)$ and operated in duplicate. The headspace $(1 \mathrm{~L})$ was purged with $\mathrm{N}_{2}(99.99 \%)$ during $20 \mathrm{~min}$. They were kept at $37^{\circ} \mathrm{C}$, during $187 \mathrm{~h}$.

\section{Analytical Methods}

The hydrogen, methane and $\mathrm{CO}_{2}$ contents in the biogas were determined simultaneously in a single gas chromatography run in a TOGA - transformer oil gas analyzer system, coupled with a Trace GC Ultra-Thermo Gas Chromatographequipped with split/splitless injector and two detectors: thermal conductivity detector (TCD) and flame ionization detector (FID), with methanizer [17]. The fraction containing hydrogen, nitrogen, and methane was analyzed in a RtMSieve $5 \mathrm{~A}^{\circ} 30 \mathrm{~m} \times 0.53 \mathrm{~mm}$ i.d. column. Hydrogen and nitrogen were detected by the TCD. $\mathrm{CO}_{2}$ was detected by the FID after passing through the methanizer. Argon was used as carrier gas (1.5 mL $\mathrm{min}^{-1}$ in splitless mode). The FID temperature was $250^{\circ} \mathrm{C}$; the TCD and injector were adjusted to $150{ }^{\circ} \mathrm{C}$. The oven programing was $50^{\circ} \mathrm{C}(4.5 \mathrm{~min})$, heating from $40^{\circ} \mathrm{C} \mathrm{min}^{-1}$ to $180{ }^{\circ} \mathrm{C}(1.5 \mathrm{~min})$ then cooling from $50{ }^{\circ} \mathrm{C} \mathrm{min}^{-1}$ to $50{ }^{\circ} \mathrm{C}$ (3.15 min).

Volatile acid and alcohols, which were present in the residual media at the end of the assay, were separated by gas chromatography, using a Shimadzu gas chromatograph (GC model 2010), equipped with a flame ionization detector, a COMBI-PAL headspace auto-sampler system (AOC 5000), and a HP-INNOWAX column $(30 \mathrm{~m} \times 0.25 \mathrm{~mm} \times 0.25 \mu \mathrm{m}$ of film thickness) [18].

Sucrose concentrations were determined by a colorimetric method [19, 20].

The adjustments of $\mathrm{pH}$ were made with the addition of hydrochloric acid or sodium hydroxide diluted solutions. The $\mathrm{pH}$ measurements were made at the beginning and at the end of the assays [20].

\section{Cellular Growth}

The cellular growth was monitored by optical density at $600 \mathrm{~nm}$ (OD600), using a spectrophotometer UV-VIS BIOSPEC SP-220 [21].

\section{Bacteria Counting by Most Probable Number (MPN)}

Most probable number (MPN) technique was performed to estimate the total of anaerobic bacteria and hydrogen producing bacteria.

The MPN were made in quintuplicate dilutions at the end of the operation of the anaerobic batch reactors. The measurements were conducted $168 \mathrm{~h}$ after incubation, by gas chromatography (hydrogen gas presence/absence), previously described and analyzed according to standard probability table [34].

\section{Molecular Biology Analysis}

At the end of the anaerobic reactors operation, the microbial community of samples from inocula I, II and III were analyzed using denaturing gradient gel electrophoresis (DGGE). The DNA extraction was made with phenol and chloroform [22]. The 16S rDNA gene was amplified through polymerase chain reaction (PCR) using 1968FGC (5'-CGC CCG GGG CGC GCC CCG GGC GGG GCG GGG GCA CGG GGG GAA CGC GAA GAA CCT TAC-3')-1401GC (5'-CGG TGT GTA CAA GAC CC-3') primers for Bacteria Domain [23]. The amplification program of genomic DNA fragments for PCR were 30 cycles, using the following method: initial denaturation at $94{ }^{\circ} \mathrm{C}$ for $5 \mathrm{~min}$, denaturation at $94{ }^{\circ} \mathrm{C}$ for $0.45 \mathrm{~min}$, annealing at $55^{\circ} \mathrm{C}$ for $0.45 \mathrm{~min}$, extension at $72^{\circ} \mathrm{C}$ for $1.0 \mathrm{~min}$, final extension at $94{ }^{\circ} \mathrm{C}$ for $7 \mathrm{~min}$, and cooling to $4{ }^{\circ} \mathrm{C}$ [24].

The amplified fragments were separated by electrophoresis on polyacrylamide gel at DGGE on TAE (Tris-AcetateEDTA) buffer at $75 \mathrm{~V}$ and $65^{\circ} \mathrm{C}$ for $16 \mathrm{~h}$ on polyacrylamide gel containing linear gradient that varies from 45 to $65 \%$ denaturant. After electrophoresis, the gel was stained with ethidium bromide for $20 \mathrm{~min}$ and read in a TMIII Eagle Eye (Stratagene) under exposure to UV at $254 \mathrm{~nm}$, coupled to a computer and software Eagle Sight. The gel bands were cut out and amplified with the same set primer, however without the GC clamp. The program of PCR procedure was: initial denaturation at $95{ }^{\circ} \mathrm{C}$ for 7 min.; denaturation at $95^{\circ} \mathrm{C}$ for $45 \mathrm{~s}$; annealing at $56^{\circ} \mathrm{C}$ for $45 \mathrm{~s}$; extension at $72{ }^{\circ} \mathrm{C}$ for $1 \mathrm{~min}$; final extension at $72{ }^{\circ} \mathrm{C}$ for $10 \mathrm{~min}$ and cooling at $4{ }^{\circ} \mathrm{C}$.

Nucleotide sequence analyses were performed by Macrogen Inc ${ }^{\circledR}$ [25]. Then they were grouped in OTU (Operational Taxonomic Unit) and compared to the National Center for Biotechnology Information (NCBI) database.

The construction of the DGGE dendrogram was performed using BioNumerics' software package (Applied Biomath, Belgium) and the similarity coefficients were calculated from the densitometric curves of the scanned DGGE profiles, using the Jaccard correlation. 
Shannon-Wiener diversity indexes were calculated based on the bands' intensities on the gel tracks. The peaks heights were evaluated in the densitometric curves, according to the Eq. (1).

$H=-\sum\left(P_{i} \ln \left(P_{i}\right)\right)$

where $\mathrm{H}$ is the diversity index and $\mathrm{P}_{\mathrm{i}}$ is the importance probability of the bands in a lane $\left(P_{i}=n_{i} / N\right.$, where $n_{i}$ is the height of an individual peak and $N$ is the sum of all peaks heights in the densitometric curves) [26].

\section{Experimental Data Adjustment}

The cumulative $\mathrm{H}_{2}$ production in the duplicates of anaerobic batch reactors was kinetically simulated by Statistica ${ }^{\circledR}$ software, version 8 . The maximum rate of hydrogen production was obtained through a non-linear sigmoidal adjust of the modified Gompertz function [27] according to the Eq. (2).

$H=P \cdot \exp \left\{-\exp \left[\frac{R m \cdot e}{P}(\lambda-t)+1\right]\right\}$

where $H$ is the cumulative $\mathrm{H}_{2}$ production (mmol), $P$ is the $\mathrm{H}_{2}$ production potential (mmol $\mathrm{H}_{2} \mathrm{~L}^{-1}$ of culture), $R m$ is the maximum $\mathrm{H}_{2}$ production rate $\left(\mathrm{mmol} \mathrm{H}_{2} \mathrm{~L} \mathrm{~h}^{-1}\right), \lambda$ is the lag phase time (h), and $e$ is 2.718281828 . The values of $P$, $R m$, and $\lambda$ for each batch experiment were estimated using the nonlinear estimation function in Statistica 8.0 software.

\section{Results and Discussion}

The gas chromatography analysis confirmed the absence of methane in the headspace of all the batch reactors. Therefore, the heat treatment applied was efficient for the inactivation of methanogenic microorganisms, which are responsible for the hydrogen consumption during the anaerobic metabolism. Wang et al. [28] conducted assays with two different strains of Clostridum perfringens (W11, W12) and obtained $1.5 \mathrm{~mol} \mathrm{H}_{2}$ mol hexose ${ }^{-1}$ after heat treatment of anaerobic cultures. Subudhi et al. [29] applied heat treatment on a crude oil source to isolate hydrogen producing bacteria and inactivate methanogenic microorganisms. They isolated E. cloacae DT-1 and used it in anaerobic batch reactors fed with $10 \mathrm{~g} \mathrm{~L}^{-1}$ of glycerol at $\mathrm{pH} 7.0$ and $37{ }^{\circ} \mathrm{C}$, obtaining $6.6 \mathrm{mmol} \mathrm{H}_{2} \mathrm{~L}^{-1}$. The present study and the authors cited have carried out heat treatment and the $\mathrm{H}_{2}$ yields for this study were, in $\mathrm{mol} \mathrm{H}_{2}$ mol of sucrose ${ }^{-1}$, (I) 1.0 , (II) 1,3 and (III) 2.0, which were higher than presented by the authors cited. It suggests the heat treatment is an efficient pretreatment to inactivate the methanogen microorganisms.

In this work, the maximum cellular growth $\left(\mathrm{ABS}_{600}\right)$ from the inocula were (I) 0.2 , (II) 0.2 , and (III) 0.5 , during 31,98 and $53 \mathrm{~h}$ of operation, respectively. The highest hydrogen production was obtained from inoculum III (granular sludge from UASB reactor treating domestic sewage), $8.1 \mathrm{mmol}$ $\mathrm{H}_{2} \mathrm{~L}^{-1}$ and these results were higher than Subuthi et al. [29] with E. cloacae DT-1, described previously. Inocula I (granular sludge from a UASB treating brewery wastewater) and II (facultative anaerobic sludge from sedimentation pond treating domestic sewage) produced 4.5 and $4.7 \mathrm{mmol} \mathrm{H}_{2}$ $\mathrm{L}^{-1}$ respectively (Table 1 ). The yields expressed in $\mathrm{mol} \mathrm{H}_{2}$ mol sucrose ${ }^{-1}$, were 1.0, 1.3, and 2.0 for I, II, and III, respectively. The results from inoculum III were higher than the $1.4 \mathrm{~mol} \mathrm{H}_{2}$ mol of sugar ${ }^{-1}$ obtained by Subudhi et al. [29]. This fact could be the evidence that in anaerobic bacteria consortia occur some interaction that favor the $\mathrm{H}_{2}$ production process. It also shows the advantages to use and carry out studies using real anaerobic bacteria consortia.

The lag phase on hydrogen generation was observed during the assays. Inoculum III showed a lag phase of $21.3 \mathrm{~h}$, with maximum hydrogen production after $60 \mathrm{~h}$. However, the reactors that operated with inocula I and II showed lag phases of 13.3 and $17.8 \mathrm{~h}$, with maximum $\mathrm{H}_{2}$ generation at 52 and $160 \mathrm{~h}$, respectively (Fig. 1). The maximum $\mathrm{H}_{2}$ production rates were $0.2,0.1$ and $0.4 \mathrm{mmol} \mathrm{H}_{2} \mathrm{~L}^{-1} \mathrm{~h}^{-1}$ for inocula I, II, and III, respectively.

Inoculum III demonstrated the best efficiency on hydrogen generation $\left(2.0 \mathrm{~mol} \mathrm{H}_{2}\right.$ mol sucrose ${ }^{-1}$ ), when compared to inocula I and II. Maintinguer et al. [9] obtained a lower efficiency $\left(1.2 \mathrm{~mol} \mathrm{H}_{2}\right.$ mol consumed sucrose $\left.{ }^{-1}\right)$, when using the granulated sludge of a UASB reactor from swine wastewaters, previously heat treated, using anaerobic batch reactors fed with $1.8 \mathrm{~g}$ sucrose $\mathrm{L}^{-1}$, pH 5.5 at $37^{\circ} \mathrm{C}$, during $240 \mathrm{~h}$ of operation. This comparison shows that the sludge generating potential is possible to be deeply related to the waste that the sludge treats in the source.

The amounts of organic acids produced were acetic acid (39.7, 42.8 and $\left.173.3 \mathrm{mg} \mathrm{L}^{-1}\right)$ and butyric acid $(73.8,157.0$ and $234.0 \mathrm{mg} \mathrm{L}^{-1}$ ) from inocula I, II, and III, respectively (Fig. 2). Comparable results were obtained by Liu et al. [30] during experiments on $\mathrm{H}_{2}$ production. They observed that the two main products of fermentation were acetic and butyric acids during the operation of anaerobic batch reactors fed with synthetic wastewater containing $5 \mathrm{~g}$ of cellulose

Table 1 Kinetic parameters of $\mathrm{H}_{2}$ production for different Tropical sludges tested in anaerobic batch reactors fed with $2 \mathrm{~g} \mathrm{~L}^{-1}$ of sucrose

\begin{tabular}{|c|c|c|c|c|}
\hline Tropical sludges & $\begin{array}{l}\mathrm{P}(\mathrm{mmol} \\
\left.\mathrm{H}_{2} \mathrm{~L}^{-1}\right)\end{array}$ & $\begin{array}{l}\mathrm{Rm} \\
\left(\mathrm{mmol} \mathrm{H} \mathrm{H}_{2}\right. \\
\left.\mathrm{L} \mathrm{h}^{-1}\right)\end{array}$ & $\lambda(\mathrm{h})$ & $\mathrm{R}^{2}$ \\
\hline (I) Brewery & 4.5 & 0.18 & 13.3 & 0.994646 \\
\hline $\begin{array}{l}\text { (II) Facultative anaerobic } \\
\text { sludge }\end{array}$ & 4.7 & 0.05 & 17.8 & 0.979170 \\
\hline (III) Domestic sewage & 8.1 & 0.39 & 21.3 & 0.993191 \\
\hline
\end{tabular}


Fig. 1 Cumulative $\mathrm{H}_{2}$ production ( $\mathrm{mmol} \mathrm{H}_{2} \mathrm{~L}^{-1}$ ) from Tropical sludges I, II, and III during the operation of anaerobic batch reactors fed with sucrose $2 \mathrm{~g}$ $\mathrm{L}^{-1}$. (I) granular sludge from a UASB reactor treating brewery wastewater; (II) facultative anaerobic sludge from sedimentation pond treating domestic sewage; (III) granular sludge from UASB reactor treating domestic sewage

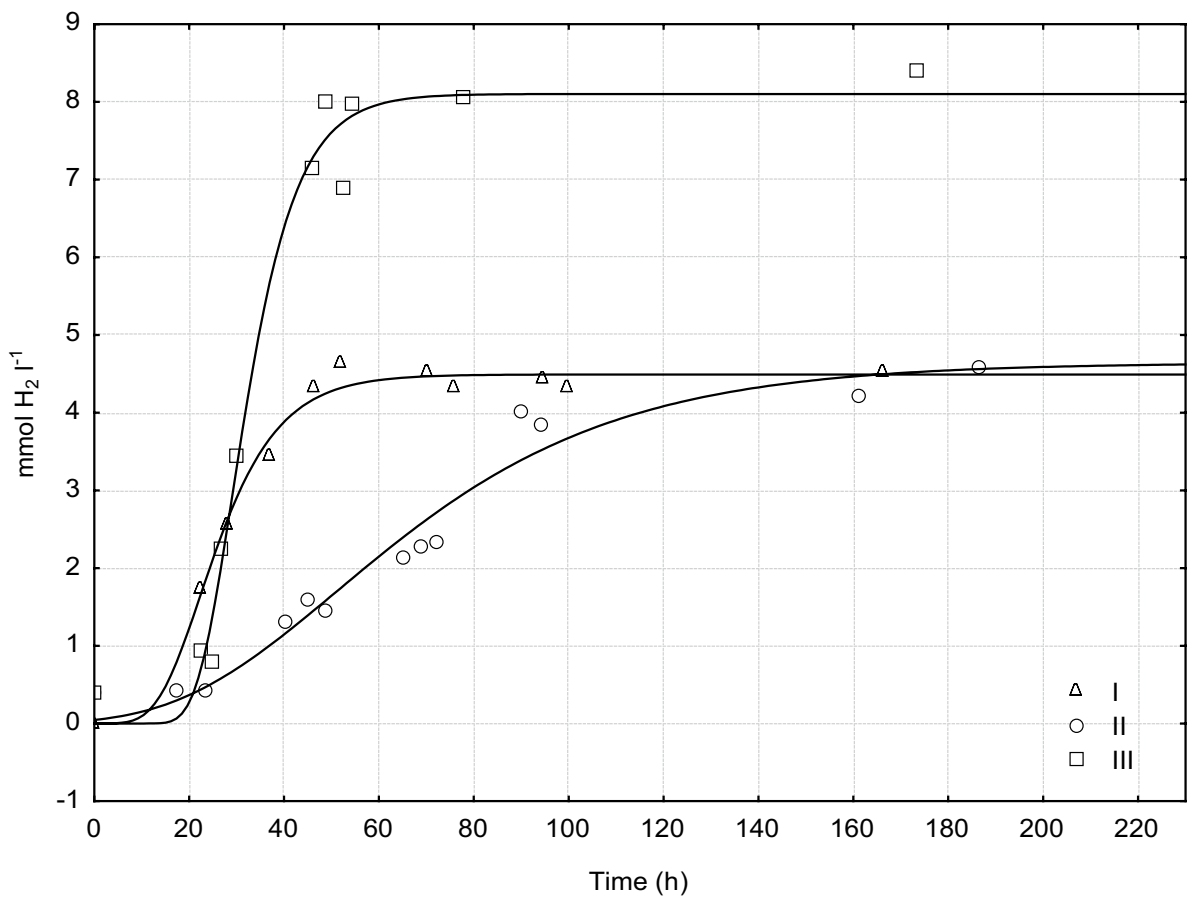

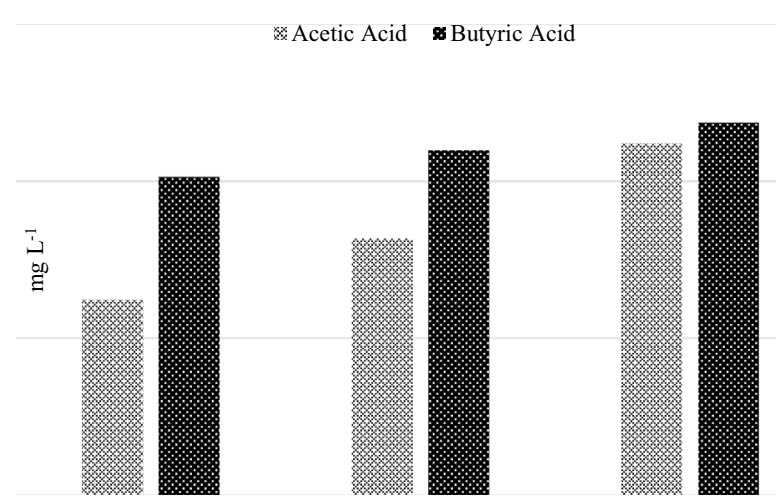

Fig. 2 Organic acids generated $\left(\mathrm{mg} \mathrm{L}^{-1}\right)$ at the end of the operation of anaerobic batch reactors fed with sucrose $\left(2 \mathrm{~g} \mathrm{~L}^{-1}\right)$ from tropical sludges (I) granular sludge from a UASB reactor treating brewery wastewater; (II) facultative anaerobic sludge from sedimentation pond treating domestic sewage; (III) granular sludge from UASB reactor treating domestic sewage

$\mathrm{L}^{-1}$ at $55^{\circ} \mathrm{C}$ with $\mathrm{pH}$ varying from 5.5 to 8.5 . Generally, the increasing in operating time during the hydrogen bioproduction provides an increasing in amounts of fatty acids [28, 31]. Wang et al. [28] conducted assays with two different strains of Clostridum perfringens (W11, W12) in reactors fed with sucrose $\left(10 \mathrm{~g} \mathrm{~L}^{-1}\right)$ for $13 \mathrm{~h}, \mathrm{pH} 7.0$, at $37^{\circ} \mathrm{C}$. The authors obtained the following amounts of fatty acids ( $\mathrm{mg}$ $\left.\mathrm{L}^{-1}\right)$ : acetic acid $(1.680 ; 1.610)$ and butyric acid $(2.280$; 2.600 ) for $\mathrm{W} 11$, and $\mathrm{W} 12$, respectively. The yields of hydrogen were 1.5 and $1.6 \mathrm{~mol} \mathrm{H}_{2}$ mol sucrose ${ }^{-1}$ for W11, and $\mathrm{W} 12$, respectively. Therefore, the bacterial consortia from the present study showed better results than the obtained by Wang et al. [28] with isolated bacteria that theoretically should show higher efficiencies. Jame et al. [31] performed a hydrogen production assay using Clostridium sp. fed with glucose $\left(5 \mathrm{~g} \mathrm{~L}^{-1}\right)$ for $19 \mathrm{~h}$ and obtained $4.2 \mathrm{mmol}$ of acetic acid $\mathrm{L}^{-1}$ and $2.7 \mathrm{mmol}$ of butyric acid $\mathrm{L}^{-1}$. Both assays conducted by Wang et al. [28] and Jame et al. [31] showed low acid production, probably due to their low operation times. As a result, Jame et al. [31] obtained $4.1 \mathrm{mmol} \mathrm{H}_{2} \mathrm{~L}^{-1}$ with glucose as substrate. Therefore, these values obtained are lower than ours from inocula I, II, and III: 4.5, 4.7, and $8.1 \mathrm{mmol} \mathrm{H}_{2} \mathrm{~L}^{-1}$, respectively. In this regard, the higher production of VFAs seems to be involved in the higher biohydrogen production when compared to the authors with lower results. It can be explained with the stochiometric equations of the $\mathrm{H}_{2}$ production from the VFAs found in these studies.

The final $\mathrm{pH}$ at the end of operation of the anaerobic batch reactors were 4.4, 3.5, and 3.4, from inocula I, II, and III, respectively. These results confirmed the decrease in $\mathrm{pH}$ was due to production of volatile fatty acids, like butyric and acetic acids, generated during the operation of the anaerobic batch reactors which deplete the buffering capacity of the medium, resulting in a lower final $\mathrm{pH}$ [32].

The bacteria count of the samples revealed higher values for total anaerobic bacteria than for $\mathrm{H}_{2}$ producing bacteria (Table 2). Sá et al. [33] obtained lower values of total anaerobic bacteria $\left(2.3 \mathrm{E}+2 \mathrm{MPN} 100 \mathrm{~mL}^{-1}\right)$ from domestic sewage sludge, pretreated on batch reactors fed with sucrose $\left(10 \mathrm{~g} \mathrm{~L}^{-1}\right)$ compared with the present study. Maintinguer et al. [24] observed lower counts of $\mathrm{H}_{2}$ 
Table 2 Bacteria count (MPN) with different tropical sludges during the operation of anaerobic batch reactors

MPN $100 \mathrm{~mL}^{-1}$

\begin{tabular}{lll}
\hline Tropical sludges & Total anaerobic bacteria & $\mathrm{H}_{2}$ producing bacteria \\
\hline I-Granular sludge from a UASB reactor treating brewery wastewater & $2.1 \mathrm{E}+10$ & $2.4 \mathrm{E}+6$ \\
II-Facultative anaerobic sludge from sedimentation pond treating domestic sewage & $>4.6 \mathrm{E}+11$ & $3.0 \mathrm{E}+2$ \\
III-Granular sludge from UASB reactor treating domestic sewage & $>1.1 \mathrm{E}+10$ & $>1.1 \mathrm{E}+10$ \\
\hline
\end{tabular}

producing bacteria with inocula from reservoir sediment previously adapted to hydrogen production with xylose as carbon source (4.3 MPN $100 \mathrm{~mL}^{-1}$ ). Our results (Table 2) are close to the obtained by Castelló et al. [34] $(>2.4 \mathrm{E}+11$ MNP $\mathrm{mL}^{-1}$ and 9.0E+11 $\mathrm{MNP} \mathrm{mL}^{-1}$ during 69 and 129 days, respectively) with inocula from an UASB reactor fed with cheese whey (67.0 COD g L ${ }^{-1}$ ), at $30{ }^{\circ} \mathrm{C}$, pH 5.0. This amount of total anaerobic bacteria could be involved in the high potential of this consortia. For bioH produc- $_{2}$ tion interactions between microorganisms are extremally important and until now just little is known. However, these interactions could contribute to cooperative work among bacteria in the consortia.

Microscopic analysis during the operation of the reactors showed the predominance of Gram-positive rods (data not shown), that are the characteristic morphologies of hydrogen producing bacteria, such as Clostridium and Bacillus species [35].
The bacterial diversity of the tropical sludges I, II, and III showed differences (Fig. 3a). The similarity index ranged between 20 and $40 \%$ among the inocula, showing a heterogeneity of the anaerobic bacteria from the tropical sludges pretreated and during the operation of the reactors fed with sucrose.

The Shannon-Wiener diversity indices (H Index) were higher for the inoculum II with pretreatment (2.42), and inoculum III with pretreatment (2.35) (Fig. 3a) when compared to the inoculum I with pretreatment (0.78). These differences could be related to the characteristics of the sanitary sewage (inocula II and III) compared to the industrial waste (inoculum I), which generally contains a lower range of carbon sources and some compounds from industrial processes that could be toxic to certain populations of microorganisms.

The decreasing of the bacterial diversity was observed between pretreated inocula [samples 3 (0.78), 1 (2.42), and 5 (2.35)] and reactivated inocula [samples 4 (0.66), 2
Fig. 3 DGGE analyses with Set Primer Bacteria Domain (968FGC-1392R): a UPGMA Dendogram based on similarity coefficient using the Jaccard Correlation; and $\mathbf{b}$ cut bands from DGGE gel for the samples [(1) tropical sludge II pretreated (pH 5.5 and heat treatment); (2) tropical sludge II reactivated with sucrose; (3) tropical sludge I pretreated ( $\mathrm{pH} 5.5+$ heat treatment); (4) tropical sludge I reactivated with sucrose; (5) tropical sludge III pretreated (pH 5.5 and heat treatment); (6) tropical sludge III reactivated with sucrose] (a)

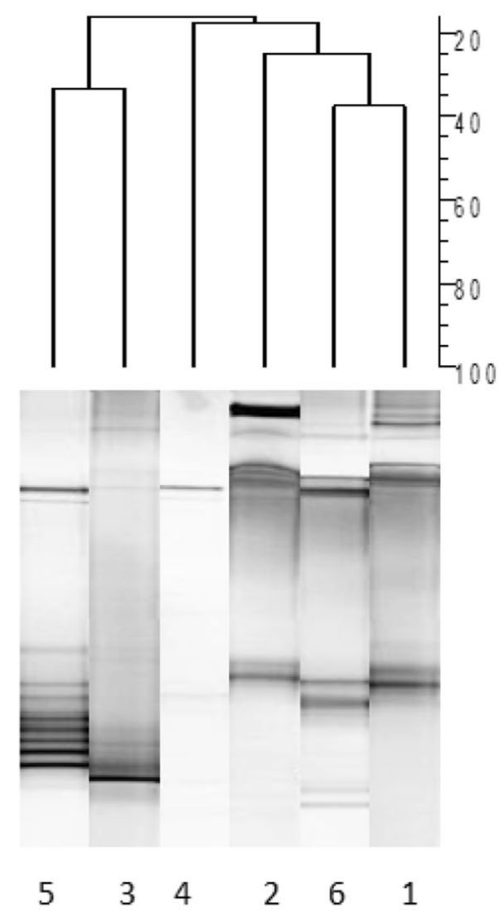

(b)

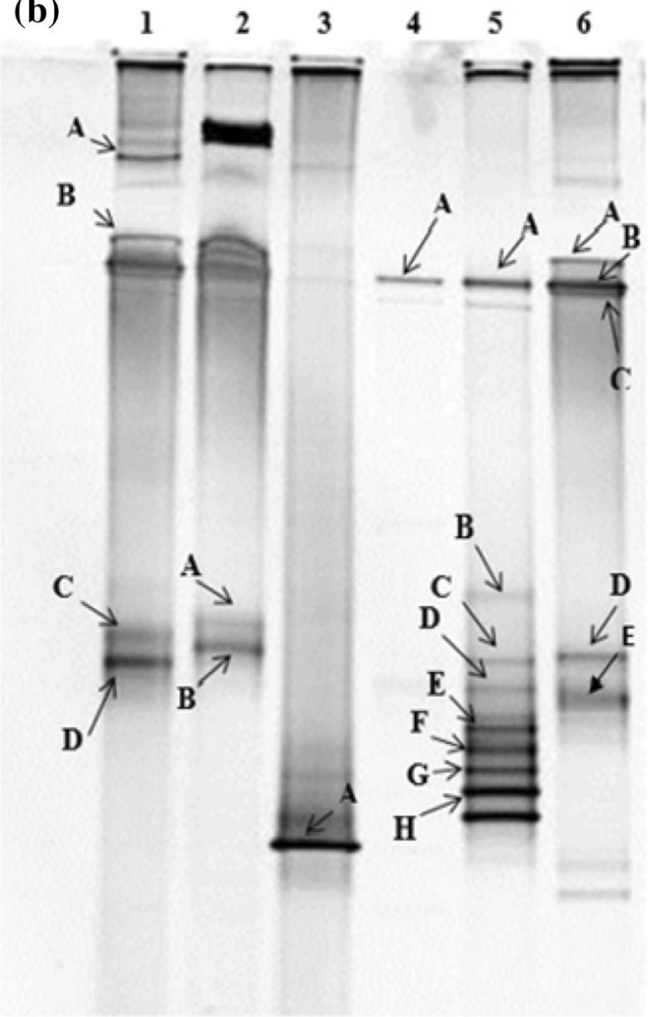


(2.15), and 6 (2.10)]. The experimental conditions imposed, selected the populations from the samples 3,1 , and 5 , which were involved in the $\mathrm{H}_{2}$ production (samples 4,2 , and 6). Abreu et al. [26] observed a decrease of the diversity during the operation of anaerobic reactors applied to $\mathrm{H}_{2}$ generation. Ratti et al. [36] observed a difference in bands' number and pattern between the original inoculum and after the pretreatment in anaerobic batch reactors fed with 2 and $4 \mathrm{~g} \mathrm{~L}^{-1}$ of glucose, applied to biohydrogen production. The authors concluded that the operating conditions imposed the inactivation of non-resistant bacteria, as it was observed in the present study.

The phylogenetic characterization beyond the bands cut, showed similarity to species like Burkholderia, Clostridium sp., Staphylococcus, Streptococcus, Bacillus e Lactobacillus (Fig. 3b; Table 3).

Clostridium sp. (OTU 1) is an anaerobic bacterium recognized as $\mathrm{H}_{2}$ producer [37]. Song et al. [1] isolated Clostridium sp. from cellulosic biomass using anaerobic batch reactors at $36{ }^{\circ} \mathrm{C}$ and obtained a maximum production of $92.9 \mathrm{~mL} \mathrm{H}_{2} \mathrm{~g}^{-1}$ of biogas. This species demonstrates higher efficiencies for hydrogen production from the cellulosic biomass. During the operation of the anaerobic batch reactors morphologies of gram-positive bacilli and endospores (data not shown) that are characteristic of Clostridium sp. were observed.

Staphylococcus sp. (OTU 2) is a facultative anaerobic bacterium with a spherical shape, gram-positive, that has optimal stability temperature between 30 and $37^{\circ} \mathrm{C}$. Microscopic analysis showed the presence of these morphologies (data not shown). Probably the experimental conditions favored the presence of Staphylococcus species in sample (2).

Burkholderia species (OTU 3) were present in bacterial population from brewery wastewater (sample I). These species of microorganisms are found in soil samples, mainly involved in $\mathrm{N}_{2}$-fixing [38] and can be found in granular sludges from anaerobic reactors and after their pretreatments [9, 39].Terrazas-Hoyos et al. [40] tested pure cultures of Burkholderia unamae and Burkholderia tropica on hydrogen generation and they obtained the best results at $\mathrm{pH} 6.0,35{ }^{\circ} \mathrm{C}$ in anaerobic batch reactors fed with a mix of sucrose, succinic acid and enzymatic cofactors such as cysteine, sodium molybdate and ferrous sulfate. These two bacteria are known as $\mathrm{N}_{2}$-fixing and in the mechanism performed by nitrogenase enzyme, $1 \mathrm{~mol}$ of $\mathrm{H}_{2}$ is produced for $1 \mathrm{~mol}$ of $\mathrm{N}_{2}$ fixed [39]. Maintinguer et al. [9] tested hydrogen bioproduction with granular sludge from UASB reactor heat-treated previously in anaerobic batch reactors fed with sucrose $\left(0.5-4.8 \mathrm{~g} \mathrm{~L}^{-1}\right)$ and they identified Clostridium, Enterobacter and Burkholderia species during the operation. Etchebehere et al. [41] affirm that Burkholderia species are producers of volatile fatty acids, and can be found in no treated sludge, so is possible to connect their presence with some variation in the heat pretreatment. The sludge from sample I (Brewery) was heat treated in an open beaker, therefore, under aerobic conditions. So is possible to conclude that the pretreatment applied in the present study was effective against methanogenic production, but some aerobic bacteria such as Burkholderia species remained present in the sludge. These species could also be involved in the biologic processes of volatile fatty acids generation [41] observed in the present study contributing to the decreasing the $\mathrm{pH}$ and, probably, had influence on the lower $\mathrm{H}_{2}$ bioproduction for sample I. However, Terrazas-Hoyos et al. [40] tested pure cultures of Burkholderia species (B. unamae and $B$. Tropica) and confirm the production of biohydrogen for these species. So, probably, bacteria which belong to Burkholderia genus identified in this study were involved in the volatile fatty acids generation [41] and in the biohydrogen production [40].

Bacillus megaterium was related to OTU 4, gram-positive rods belonging to the Bacillus genus. It has several metabolic genes that may be useful in bioremediation [42]. These microorganisms have the capability of dissolving natural phosphorus compounds from soil. The gram-positive rods observed in this study could be Bacillus megaterium, which are often involved in the fermentation process of hydrogen production.

Table 3 Phylogenetic characterization of bands and subsequent operational taxonomic units (OTUs) clustering from DGGE analyses

\begin{tabular}{|c|c|c|c|c|c|c|}
\hline OTU & Bands & Inoculum & Affiliation & Access & Similarity (\%) & Base-pairs \\
\hline 1 & $1 a, 1 b, 1 c, 1 d, 6 a, 6 b, 6 c$ & $\begin{array}{l}\text { II (ph } 5.5 \text { and heat treatment); III } \\
\text { reactivated }\end{array}$ & Clostridium sp. & JN688047.1 & 99 & 450 \\
\hline 2 & $2 \mathrm{a}, 2 \mathrm{~b}$ & II reactivated & Staphylococcus sp. & KF646741.1 & 99 & 445 \\
\hline 3 & $3 a$ & I ( $\mathrm{pH} 5.5$ and heat treatment) & Burkholderia sp.KBS0801 & JQ437592.1 & 99 & 449 \\
\hline 4 & $4 \mathrm{a} 5 \mathrm{a}$ & $\begin{array}{l}\text { I reactivated; } \mathrm{III} \text { (pH } 5.5 \text { and } \\
\text { heat treatment) }\end{array}$ & Bacillus megaterium & JQ833485.1 & 94 & 205 \\
\hline 5 & $5 \mathrm{~b}, 5 \mathrm{c}, 5 \mathrm{~d}, 5 \mathrm{e}, 5 \mathrm{f}, 5 \mathrm{~g}, 5 \mathrm{~h}, 6 \mathrm{~d}$ & $\begin{array}{l}\text { III ( } \mathrm{pH} 5.5 \text { and heat treatment); } \\
\text { III reactivated }\end{array}$ & Bacillus subtilis 131 & JQ795145.1 & 99 & 431 \\
\hline 6 & $6 e$ & III reactivated & Lactobacillus sp.JCM 7747 & AB911486.1 & 98 & 450 \\
\hline
\end{tabular}


Table 4 Comparative study on efficiency of hydrogen production in anaerobic batch reactors

\begin{tabular}{|c|c|c|c|c|c|c|}
\hline Seed sludge & $\begin{array}{l}\mathrm{pH} \\
\mathrm{T}\end{array}$ & $\begin{array}{l}\text { Substrate } \\
\left(\mathrm{g} \mathrm{L}^{-1}\right)\end{array}$ & $\begin{array}{l}\text { Yield mol } \mathrm{H}_{2} \\
\text { mol substrate }\end{array}$ & Metabolites generating & Identified bacteria & Ref. \\
\hline Soil & $\begin{array}{l}\mathrm{pH} 7.0 \\
37^{\circ} \mathrm{C}\end{array}$ & Sucrose (10) & 1.5 & $\begin{array}{l}\text { Lactic acid } \\
\text { Acetic acid } \\
\text { Butyric acid }\end{array}$ & Clostridium perfringens & {$[24]$} \\
\hline Crude oil & $\begin{array}{l}\mathrm{pH} 7.0 \\
37^{\circ} \mathrm{C}\end{array}$ & Glucose (10) & 1.4 & $\begin{array}{l}\text { Acetic acid } \\
\text { Ethanol }\end{array}$ & Enterobacter cloacae & {$[25]$} \\
\hline Activated sludge & $\mathrm{pH} 7.037^{\circ} \mathrm{C}$ & Glycerol (5) & 1.3 & $\begin{array}{l}\text { Formic acid } \\
\text { Malic acid } \\
\text { Citric acid } \\
\text { Acetic acid } \\
\text { Propionic acid }\end{array}$ & Clostridium sp. & [27] \\
\hline $\begin{array}{l}\text { I } \\
\text { II } \\
\text { III }\end{array}$ & $\begin{array}{l}\text { pH } 5.5 \\
37^{\circ} \mathrm{C}\end{array}$ & Sucrose (2) & $\begin{array}{l}1.0 \\
1.3 \\
2.0\end{array}$ & $\begin{array}{l}\text { Acetic acid } \\
\text { Butyric acid }\end{array}$ & $\begin{array}{l}\text { Clostridium } \mathrm{sp} . \\
\text { Staphylococcus } \mathrm{sp} . \\
\text { Burkholderia } \mathrm{sp} . \\
\text { Bacillus megaterium } \\
\text { Bacillus subtilis } \\
\text { Lactobacillus } \mathrm{sp} .\end{array}$ & Present study \\
\hline
\end{tabular}

The OTU 5 was related to Bacillus subtilis, as reported by Mohanapriya et al. [2], who isolated that species from contaminated soil. They operated reactors fed with glucose $\left(1 \mathrm{~g} \mathrm{~L}^{-1}\right)$ during $24 \mathrm{~h}$ at $37^{\circ} \mathrm{C}$ with hydrogen generations of 1.5 and $3.3 \mathrm{~mol} \mathrm{H}_{2}$ mol glucose ${ }^{-1}$. The authors concluded that the Bacilli class was important in hydrogen production, coherent with the findings reported in the present study which has found Bacilli class bacteria in the morphology analyses.

The OTU 6 was related to the Lactobacillus Genus, which was reported by Kawagoshi et al. [35]. It can contribute adversely to the production of hydrogen since it produces lactate and consumes hydrogen during the fermentative process.

The $\mathrm{H}_{2}$ yield for inoculum III was slightly higher than the ones observed in the literature (Table 4), even though all authors cited had used isolated bacteria and pure cultures. Additionally, our results on hydrogen yields with anaerobic bacteria consortia were higher than the ones in the literature (Table 4) with pure cultures, which theoretically, could show better hydrogen productions. Furthermore, some metabolites generated in the cited papers were mostly lactic acid and ethanol, which may consume $\mathrm{H}_{2}$ for their formation, resulting in lower yields of hydrogen production, as observed. The best results obtained with mesophilic consortia of anaerobic bacteria could explain the inocula from tropical sludges, such as hydrogen producing bacteria, have ideal conditions of surviving and producing hydrogen, as observed.

\section{Conclusions}

The use of TOGA-Transformer Oil Gas Analyzer System-that analyses hydrogen, methane and $\mathrm{CO}_{2}$ in a single chromatographic run, proved to be an efficient tool and can be applied for rapid and simultaneous determination of hydrogen, methane and $\mathrm{CO}_{2}$ in anaerobic fermentation systems.

The heat treatment applied on tropical sludges used in this study was effective in inactivating the methanogen microorganisms that consume $\mathrm{H}_{2}$.

The results obtained suggest the role of anaerobic bacteria consortia, mainly Clostridium, Burkholderia and Bacillus species which could be found in sludges used in this study for biological production of $\mathrm{H}_{2}$.

The application of tropical sludges from biologic treatment plants' wastewater in hydrogen producing anaerobic reactors suggest it uses a sustainable alternative as feedstock for bioenergy and biofuels production.

The $\mathrm{H}_{2}$ production obtained from tropical sludges opens the possibility to explore the abundant sugars present in waste food industries and agroindustrial effluents, to promote the integrated development of this technology in a complementary way in regions with similar conditions of tropical countries.

Acknowledgements The authors acknowledge Fundação de Amparo a Pesquisa do Estado de São Paulo (FAPESP_Process No. 2012/0131801 ) and Fundação para o Desenvolvimento da Unesp (Fundunesp Process 1001/2003) for financial support, and Cempeqc (Center for Monitoring and Researching the Quality of Fuels, Biofuels, Crude Oil, and Derivatives) for the laboratory facilities. 


\section{References}

1. Song, X., Dai, Y., Fan, Q.L., Li, X.H., Fan, Y.T., Hou, H.W.: Effects of pretreatment method of natural bacteria source on microbial community and bio-hydrogen production by dark fermentation. Int. J. Hydrog. Energy 37, 5631-5636 (2012)

2. Mohanapriya, C., Krishnaven, M.: Gas chromatography analysis for hydrogen production from Bacillus subtilis MKMP. Int. J. Chem. Anal. Sci. 4, 182-184 (2013)

3. Maintinguer, S.I., Fernandes, B.S., Saavedra, N., Duarte, I., Adorno, M.A.T., Varesche, M.B.A.: Fermentative hydrogen production with xylose by Clostridium and Klebsiella species in anaerobic batch reactors. Int. J. Hydrog. Energy 36, 13508-13517 (2011)

4. Lorencini, P., Siqueira, M.R., Maniglia, B.C., Tapia, D.R., Maintinguer, S.I., Reginatto, V.: Biohydrogen production from liquid and solid fractions of sugarcane bagasse after optimized pretreatment with hydrochloric acid. Waste Biomass Valor. 7(5), 1017-1029 (2016)

5. Martinelli, L.A., Filoso, S.: Expansion of sugarcane ethanol production in brazil: environmental and social challenges. Ecol. Appl. 18(4), 885-898 (2008)

6. Rudorff, B.F.T., Aguiar, D.A., Silva, W.F., Sugawara, L.M., Adami, M., Moreira, M.A.: Studies on the rapid expansion of sugarcane for ethanol production in São Paulo State (Brazil) using Landasat Data. Remote Sens. 2, 1057-1076 (2010)

7. Nonino, C.A. Maiores usinas de álcool são da região de Ribeirão Preto. COPERCANA. (2009)http://www.copercana.com.br/index . php? $x$ var $=$ ver-ultimas $\& i d=3354$

8. United States Department of Agriculture. National Agricultural Statistics Service, 2015. Florida Citrus Statistics 2013-2014, USDA-NASS. https://www.nass.usda.gov/Statistics_by_State/ Florida/Publications/Citrus/fcs/2013-14/fcs1314.pdf. Accessed 28 Apr 2016

9. Maintinguer, S.I., Fernandes, B.S., Saavedra, N., Duarte, I., Adorno, M.A.T., Varesche, M.B.A.: Fermentative hydrogen production by microbial consortium. Int. J. Hydrog. Energy 33, 4309-4317 (2008)

10. Lin, C.Y., Cheng, C.H.: Fermentative hydrogen production from xylose using anaerobic mixed microflora. Int. J. Hydrog. Energy 31, 832-840 (2006)

11. Das, D., Veziroglu, T.N.: Hydrogen production by biological processes: a survey of literature. Int. J. Hydrog. Energy 26, 13-28 (2001)

12. Levin, B., Pitt, L., Love, M.: Biohydrogen production: prospects and limitations to practical application. Int. J. Hydrog. Energy 29, 173-185 (2004)

13. Oh, S.E., Ginkel, S.V., Logan, B.E.: The relative effectiveness of $\mathrm{pH}$ control and heat treatment for enhancing biohydrogen gas production. Environ. Sci. Technol. 37, 5186-5190 (2003)

14. Del Nery, V.: PhD Thesis. Use of anaerobic sludge immobilized in gel in the study of the departure of reactors with upflow sludge blanket. Engineering School of São Carlos, São Paulo University, São Carlos, São Paulo State, Brazil (1987)

15. Rossi, D.M., Costa, J.B., Souza, E.A., Peralba, M.C.R., Samios, D., Ayub, M.A.Z.: Comparison of different pretreatment methods for hydrogen Production using environmental microbial on residual glycerol from biodiesel. Int. J. Hydrog. Energy 36, 4814-4819 (2011)

16. Widdel, F., Pfennig, N.:. Genus Desulfobacter. In Bergey's Manual of Systematic Bacteriology, p. 1599 (1984)

17. Dhole, V., Kadam, V.: Advantages of the TOGA-Transformer Oil Gas Analyzer Involving Headspace-GC Analysis and a DGA System. Application note 10348. Thermo Fisher Scientific, Nasik (2012)
18. Adorno, M.A.T., Hirasawa, J.S., Varesche, M.B.A.: Development and validation of two methods to quantify volatile acids (C2-C6) by GC/FID: headspace (automatic and manual) and liquid-liquid extraction (LLE). Am. J. Anal. Chem. 5, 406-414 (2014)

19. Dubois, M., Gilles, K.A.K.A., Hamilton, J.K.J., Rebers, P.A., Smith, F.: Colorimetric method fordetermination of sugars and related substances. Anal. Chem. 28, 350-356 (1956)

20. Herbert, D., Philipps, O.S., Strang, R.E.: Carbohydrate analysis. Methods Enzymol. 5B, 265-277 (1971)

21. American Public Health Association/American Water Works Association/Water Environment Federation (APHA/AWWA/ WEF) (2005) Standard Methods for the Examination of Water and Wastewater, 21st edn. American Public Health Association, Washington DC

22. Griffiths, R.I., Whiteley, A.S., O'Donnell, A.G.: Rapid method for coextration of DNA and RNA from natural environments for analysis of ribosomal DNA and rRNA-based microbial community composition. Appl. Environ. Microbiol. 66, 5488-5491 (2000)

23. Nubel, U., Engelen, B., Felske, A., Snaidr, J., Wieshuber, A., Amann, R.I., Ludwig, W., Backhaus, H.: Sequence heterogeneities of genes encoding 16S rRNAs in Paenibacilluspolymyxa detected by temperature gradient gel electrophoresis. J. Bacteriol. 178(19), 5636-5643 (1996)

24. Maintinguer, S.I., Sakamoto, I.K., Adorno, M.A.T., Varesche, M.B.A.: Bacterial diversity from environmental sample applied to bio-hydrogen production. Int. J. Hydrog. Energy 40, 3180-3190 (2015)

25. http://www.macrogen.com

26. Abreu, A.A., Alves, J.I., Pereira, M.A., Sousa, D.Z., Alves, M.M.: Strategies to suppress hydrogen-consuming microorganisms affect macro and micro scale structure and microbiology of granular sludge. Biotechnol. Bioeng. 108, 1766-1775 (2011)

27. Lay, J.Y., Li, Y.Y., Noike, T.: Developments of bacterial population and methanogenic activity in a laboratory-scale landfill bioreactor. Water Res. 32, 3673-3679 (1998)

28. Wang, R., Zong, W., Qian, C., Wei, Y., Yu, R., Zhou, Z.: Isolation of Clostridium perfringens strain W11 and optimization of its biohydrogen production by genetic modification. Int. J. Hydrog. Energy 36, 12159-12167 (2011)

29. Subudhi, S., Nayak, T., RamKumar, N., Vijayananth, P., Lal, B.: Impact of regulated $\mathrm{pH}$ on proto scale hydrogen production from xylose by an alcaline tolerant novel bacterial strain, Enterobacter cloacae DT-1. Int. J. Hydrog. Energy 38, 2728-2737 (2013)

30. Liu, H., Zhang, T., Fang, H.H.P.: Thermophilic $\mathrm{H}_{2}$ productionfrom a cellulose-containing wastewater. Biotechnol. Lett. 25, 365-369 (2003)

31. Jame, R., Vilímová, V., Lakatos, B., Vaereek, L.: The hydrogen production by anaerobic grown on glucose and glycerol. Acta Chim. Slov. 4, 145-157 (2011)

32. Khanal, S.K., Chen, W.H., Li, L., Sung, S.: Biological hydrogen production: effects and intermediate products. Int. J. Hydrog. Energy 29, 1123-1131 (2004)

33. Sá, L.R.V., Cammarota, M.C., Oliveira, T.C., Oliveira, E.M.M., Matos, A., Ferreira-Leitão, V.S.: Pentoses hexoses and glycerin as substrates for biohydrogen production: an approach for Brazilian biofuel integration. Int. J. Hydrog. Energy 38, 2986-2997 (2013)

34. Castelló, E., Santos, C.G., Iglesias, T., Paolino, G., Wenzel, J., Borzacconi, L., Etchebehere, C.: Feasibility of biohydrogen production from cheese whey using a UASB reactor: links between microbial community and reactor performance. Int. J. Hydrog. Energy 34, 5674-5682 (2009)

35. Kawagoshi, Y., Hino, N., Fujimoto, A., Nakao, M., Fujita, Y., Sugimur, S., Furukawa, K.: Effect of seed sludge conditioning on hydrogen fermentation and $\mathrm{pH}$ effect on bacterial community relevant to hydrogen production. J. Biosci. Bioeng. 100,(5), 524-530 (2005) 
36. Ratti, R.P., Botta, L.S., Sakamoto, I.K., Silva, E.L., Varesche, M.B.A.: Production of $\mathrm{H}_{2}$ from cellulose by rumen microorganisms:effects of inocula pre-treatment and enzymatic hydrolysis. Biotechnol. Lett. 36, 537-546 (2014)

37. Zhao, L., Cao, G., Wang, A., Guo, W., Liu, B., Ren, H., Ren, N., Ma, F.: Enhanced bio-hydrogen production by immobilized Clostridium sp. T2 on a new biological carrier. Int. J. Hydrog. Energy 37, 162-166 (2012)

38. Hoffman, M.B., Lukoynov, D., Yang, Z.Y., Dean, D.R., Seefeldt, L.: Mehcanism of nitrogen fixation by nitrogenase: the next stage. Chem. Rev. 114, 4041-4062 (2014)

39. Shida, G.M., Sader, L.T., Amorim, E.L.C., Sakamoto, I.K., Maintinguer, S.I., Saavedra, N.K., Varesche, M.B.A., Silva, E.L.: Performance and composition of bacterial communities in anaerobic fluidized bed reactors for hydrogen production: effects of organic loading rate and alkalinity. Int. J. Hydrog. Energy 37, 16925-16934 (2012)
40. Terrazas-Hoyo, H., Portugal, M.E., Sánches, S.E., Ortiz-Hernandez, M.L.: Evaluation of the potential hydrogen production by diazotrophic Burkholderia species. Int. J. Hydrog. Energy 39, 3142-3151 (2014)

41. Etchebehere, C., Castelló, E., Wnzel, J., Anzola-Rojas, M.P., Borzacconi, L., Buitrón, G., Cabrol, L., Carminato, V.M., CarrilloReyes, J., Cisneros-Pérez, C., Fuentes, L., Moreno-Andrade, I., Razo-Flores, E., Filippi, G.R., Tapia-Venegas, E., Toledo-Alarcón, J., Zaiat, M.: Microbial communities from 20 different hydrogenproducing reactors studied by 454 pyrosequencing. Appl. Microbiol. Biotechnol. 100(Issue 7), 3371-3384 (2016)

42. Vary, P.S., Biedendieck, R., Fuerch, T., Meinhardt, F., Rohde, M., Deckwer, W.D., Jahn, D.: Bacillus megaterium —from simple soil bacterium to industrial protein production host. Appl. Microbiol. Biotechnol. 76, 957-967 (1998) 